\title{
Dengue Hemorrhagic Fever and House Conditions in Kupang City, East Nusa Tenggara Province
}

\section{Demam Berdarah Dengue dan Kondisi Rumah di Kota Kupang, Provinsi Nusa Tenggara Timur}

\author{
Wanti*, Ririh Yudhastuti**, Hari B Notobroto**, Sri Subekti***, Oktafianus Sila*, Ragu H Kristina*, Febi \\ Dwirahmadi****
}

\begin{abstract}
*Health Polytechnic Kupang, Indonesia, **Faculty of Public Health, Universitas Airlangga, Surabaya, Indonesia, ***Fisheries Faculty, Universitas Airlangga, Surabaya, Indonesia, ****School of Medicine, Griffith University, Brisbane, Australia
\end{abstract}

\begin{abstract}
Kupang, East Nusa Tenggara is an area with low rainfall where the highest East Nusa Tenggara number of Dengue Hemorrhagic Fever (DHF) cases are recorded; this number is also higher than the national figure. This study analyzed the relationship between housing conditions and DHF incidence in Kupang City. This observational study used a case-control method with $240 \mathrm{DHF}$ patient cases and 280 not patient controls without DHF from 12 villages in the rainy season and 13 villages in the dry season. The following data were collected: house size, house lighting, house temperature, water usage, wall construction, ventilation size, ventilation condition, and ownership of a clean water facility. These data were analyzed using t-test and Chi-square test. The following house condition variables were significantly related to DHF incidence ( $p$-value $\leq 0.05$ ): house lighting, water usage, house wall, ventilation area, and ownership of clean water facilities. This means that house condition is related to the incidence of dengue in Kupang City. Attention and intervention are needed in these areas, as well as attention to other factors outside house condition.
\end{abstract}

Keywords: Dengue Hemorrhagic Fever, house wall, lighting, ventilation, water

\begin{abstract}
Abstrak
Kupang merupakan daerah dengan curah hujan rendah dengan kasus demam berdarah dengue (DBD) selalu tertinggi di Provinsi Nusa Tenggara Timur dan juga lebih tinggi dari angka nasional. Penelitian ini bertujuan untuk menganalisis hubungan antara kondisi rumah dan kejadian DBD di Kota Kupang. Penelitian observasional ini menggunakan studi kasus kontrol dengan 240 pasien DBD sebagai kasus dan 280 bukan pasien DBD sebagai kontrol dari 12 desa di musim hujan dan 13 desa di musim kemarau. Data kondisi rumah yang dikumpulkan meliputi luas rumah, pencahayaan, suhu, penggunaan air, dinding, luas ventilasi, kondisi ventilasi dan kepemilikan fasilitas air bersih kemudian dianalisis dengan uji t dan uji kai kuadrat. Beberapa variabel kondisi rumah secara signifikan berhubungan dengan kejadian DBD (nilai $p \leq 0.05$ ), yaitu pencahayaan, penggunaan air, konstruksi dinding, area ventilasi dan kepemilikan fasilitas air bersih. Hal ini berarti kondisi rumah berhubungan dengan kejadian demam berdarah di Kota Kupang, sehingga perlu ada perhatian dan intervensi secara khusus terhadap kondisi rumah selain memperhatikan faktor-faktor lain di luar kondisi tersebut. rumah.
\end{abstract}

Kata Kunci: Demam berdarah dengue, dinding rumah, pencahayaan, ventilasi, air

How to Cite: Wanti, Yudhastuti R, Notobroto HB, Subekti S, Sila O, Kristina $\mathrm{RH}$, Dwirahmadi F. Dengue hemorrhagic fever and house conditions in Kupang City, East Nusa Tenggara Province. Kesmas: National Public Health Journal. 2019; 13 (4): 177-182. (doi:10.21109/kesmas.v13i4.2701)
Correspondence: Wanti, Health Polytechnic Kupang, Jl. Piet A. Tallo Liliba, Kupang, East Nusa Tenggara, email: trivena78@yahoo.com, Phone: +62 8113830302

Received : October $24^{\text {th }} 2018$

Revised : November 30th 2018

Accepted : March 27th 2019 


\section{Introduction}

Dengue Hemorrhagic Fever (DHF) is a vector borne disease that is transmitted through the bite of Aedes $s p$. mosquitoes infected with Dengue virus. Due to its contribution to the disease burden, high mortality rates, poverty, and social burden in the world, especially intropical and subtropical regions, DHF is still a major global problem. ${ }^{1-3}$ Globally, at least 128 countries infected by Dengue and 4 million people live in at risk Dengue transmission area. ${ }^{4}$ DHF is endemic to a number of Indonesian regions, including the Province of East Nusa Tenggara. In the city of Kupang, which is the capital of East Nusa Tenggara Province, they recorded the highest number of dengue cases in East Nusa Tenggara from 1999 to 2014, and every year, the number of cases in this region upper the national average.

Low rainfall is usually followed by low air humidity, which correlated positively with each other in previous studies. ${ }^{5}$ High rainfall, especially over $200 \mathrm{~mm}$, also stabilizes the density of Aedes mosquitoes, and the density of Aedes usually rises after the rainy season arrives. ${ }^{6}$ This is related to the increasing number of natural places for Aedes to breed outside the house because of the practice of storing water in outdoor containers. ${ }^{6}$ Previous studies have shown that climate variables strongly influence Dengue virus and Dengue vectors. These were such as temperature influenced development, survival, and reproduction of Dengue vectors, and also influenced on virus replication and transmission. ${ }^{7}$ However, these conditions were different in Kupang City; even though it has low rainfall, the number of DHF cases is always high. In Kupang City, DHF cases are found in both the rainy and the dry seasons. Patterns of DHF incidence rate (IR) in Kupang City do not always follow rainfall patterns; for example, in 2011, rainfall rose but IR fell, while in 2012, rainfall fell but IR rose. In 2013, rainfall rose and IR went down. 8,9

The incidence of disease is a result of the interaction between Host, Agent, and Environment, better known as Triangle Epidemiology. ${ }^{10}$ Important elements of dengue fever are the dengue virus, Aedes mosquitoes, and humans, where the three elements are influenced by the environment. The disease will continue to occur as long as treatment is only applied in one area without trying to control existing environmental risk factors and current conditions.

Diseases including DHF are local specific phenomena that include ecosystems covering the environment, population, and administrative areas. ${ }^{11}$ These various DHF incidence factors differ from one place to another and cause the degree of endemicity to differ by place and time. Therefore, there is a need for a special study on DHF incidence in the dry areas of Kupang City, which is expected to be a factor in controlling dengue risk factors in Kupang City.

Housing quality factors such as lighting, humidity, temperature, and house construction, as well as home sanitation conditions, also play a role in providing places for the breeding and presence of Aedes sp.. ${ }^{12}$ This study demostrates the importance of the role of home conditions on the presence of Aedes sp.; it also analyzes the relationship of house condition to DHF incidence. It is expected that the result of this study will be useful in controlling DHF incidence; namely, the prevention of dengue fever by improving housing conditions in Kupang City.

\section{Method}

This was an observational analytic study using a casecontrol design that compares cases (DHF patients) and controls (non-DHF patients), and then restrospectively analyzes at risk factors. The study population was two samples of people in Kupang City: cases or people with dengue fever (DHF patients) and the control group of people who were not DHF patients, all of whom lived in proximity to dengue patients within a radius of 100 meters in one village at the time the study was conducted. The sample size was 20 people for each village consisting of DHF patients and non-DHF patients. The total sample was 500 people from 25 villages. The locations and samples used in the dry and rainy seasons differed depending on the location of the cases at the time the study was conducted. Samples were taken by cluster sampling because DHF cases were few and spread out among several villages. ${ }^{13}$

Study variables were DHF (DHF and non-DHF), house size, lighting, temperature, water usage, wall construction (permanent and non-permanent), ventilation size (qualify if at least $10 \%$ of house size and not qualify if less than $10 \%$ of house size), the ventilation condition (always closed and not always closed), clean water facility ownership (own and not own). All data were collected by observation and measuring directly in sample houses. The equipment used to collect data included a luxmeter, checklist, thermometer, and length measurement instrument.

The collected data was then analyzed statistically using frequency distribution, bivariate analysis using t-test for ratio data scale and chi square test for nominal data scale. This study is part of a study approved for ethics by the faculty of the Public Health Airlangga University, protocol number: 521-KEPK, October 2016.

\section{Results}

The average size of the houses did not differ much between DHF patients and non-DHF patients; namely, $54.49 \mathrm{~m}^{2}$ for DHF patients and $55.61 \mathrm{~m}^{2}$ for non-DHF patients. There was no statistically significant relationship between house size and incidence of DHF ( $p$-value 
Table 1. Relationship of Home Size, Lighting, Temperature, Water Usage, and Home Distance to the Plants with Dengue Hemorrhagic Fever Incidence in Kupang City

\begin{tabular}{|c|c|c|c|c|c|c|}
\hline Variable & Status & Sample (n) & Mean & SD & Min-Max & p-Value \\
\hline \multirow[t]{2}{*}{ House size $\left(\mathrm{m}^{2}\right)$} & DHF & $37(7.4 \%)$ & 54.49 & 17.570 & $16-99$ & \multirow[t]{2}{*}{0.716} \\
\hline & Non-DHF & $463(92.6 \%)$ & 55.61 & 18.188 & $20-156$ & \\
\hline \multirow[t]{2}{*}{ Home lighting (luks) } & DHF & $37(7.4 \%)$ & 51.700 & 32.768 & $21.5-209.8$ & \multirow[t]{2}{*}{0.038} \\
\hline & Non-DHF & $463(92.6 \%)$ & 61.661 & 27.592 & $9.5-224.8$ & \\
\hline \multirow[t]{2}{*}{ Home temperature $\left({ }^{\circ} \mathrm{C}\right)$} & DHF & $37(7.4 \%)$ & 32.184 & 1.819 & $28.8-35.3$ & \multirow[t]{2}{*}{0.060} \\
\hline & Non-DHF & $463(92.6 \%)$ & 32.778 & 1.466 & $28.6-36.5$ & \\
\hline \multirow[t]{2}{*}{ Water usage (liter/person/day) } & DHF & $37(7.4 \%)$ & 48.632 & 20.868 & $18.5-111.1$ & \multirow[t]{2}{*}{0.004} \\
\hline & Non-DHF & $463(92.6 \%)$ & 59.971 & 33.088 & $7.3-166.7$ & \\
\hline
\end{tabular}

Notes: $\mathrm{SD}=$ Standard Deviation; $\mathrm{p}$-Value $=$ significant value

\begin{tabular}{|c|c|c|c|c|c|}
\hline Variable & Category & DHF Patients & Non-DHF Patients & p-Value & OR $(95 \% \mathrm{CI})$ \\
\hline \multirow[t]{2}{*}{ Wall construction } & Not permanent & $17(45.9 \%)$ & $39(8.4 \%)$ & \multirow[t]{2}{*}{0.000} & 9.240 \\
\hline & Permanent & $20(54.1 \%)$ & $424(91.6 \%)$ & & $(4.476-19.080)$ \\
\hline \multirow[t]{2}{*}{ Ventilation size } & Not qualify & $30(81.1 \%)$ & $173(37.4 \%)$ & \multirow[t]{2}{*}{0.000} & 7.184 \\
\hline & Qualify & $7(18.9 \%)$ & $290(62.6 \%)$ & & (3.089-16.707) \\
\hline \multirow[t]{2}{*}{ Ventilation condition } & Closed & $17(45.9 \%)$ & $153(33.0 \%)$ & \multirow[t]{2}{*}{0.157} & 1.722 \\
\hline & Opened & $20(54.1 \%)$ & $310(67.0 \%)$ & & $(0.877-3.382)$ \\
\hline \multirow[t]{2}{*}{ Ownership of clean water facility } & Not own & $26(70.3 \%)$ & $240(51.8 \%)$ & \multirow[t]{2}{*}{0.046} & 2.196 \\
\hline & Own & $11(29.7 \%)$ & $223(48.2 \%)$ & & $(1.060-4.549)$ \\
\hline
\end{tabular}

Notes: $\mathrm{OR}=$ Odds Ratio; $\mathrm{CI}=$ Confidence Interval; $\mathrm{DHF}=$ Dengue Hemorrhagic Fever

$>0.05)$.

The natural house lighting house was lower in the DHF patients' houses, and there was a significant relationship between lighting and the incidence of DHF ( $p$ value $\leq 0.05$ ), as shown in Table 1 . House temperatures were almost the same between the DHF patient group and the non-DHF patient group, and they were statistically not related to DHF incidence ( $p$-value > 0.05). Table 1 also shows that water usage in Kupang City was found to be significantly associated with DHF incidence (p-value $\leq 0.05)$.

Table 2 shows that the wall construction for most of the houses is permanent, but non-permanent houses were statistically associated with DHF incidence ( $p$-value $\leq 0.05$ ), with OR 9.240. House ventilation in DHF patients was more unqualified ( $<10 \%$ of floor area). Overall ventilation in houses that did not meet the requirements had a risk of DHF 7.184 times higher than those who met the requirements ( $p$-value $\leq 0.05$ ).

Most house ventilation are always open in both DHF patient and non-DHF patients' houses, and statistically there is no relationship between ventilation condition and the incidence of DHF ( $\mathrm{p}$-value $>0.05$ ), as shown in Table 2. Most of the existing clean water facilities are not self owned $(51.8 \%)$, and the risk of DHF incidence is 2.196 higher than for those with self owned clean wa- ter facilities ( $\mathrm{p}$-value $\leq 0.05$ OR 2.196 ), as shown in Table 2.

\section{Discussion}

This study found that several house conditions were significantly related to DHF incidence; specifically, house lighting, water usage, wall construction, ventilation size, and ownership of clean water facilities. This study did not find a relationship between DHF incidence and house size, house temperature, and ventilation condition.

House density depends on the size of the house compared to the number of occupants, so a wider house typically has a lower density. However, in this study, this condition proved different: the wider the house, the more family members live there, so the density of the house is higher. This is due to a strong family culture in East Nusa Tenggara, especially for those who live at a higher economic level. Often those with larger houses and economic levels will be more likely to invite relatives or other non-family members to live in his house, both to be assigned to look after the house or to be educated to a higher level of education. This causes large houses will also have a high occupancy density because of the extended family culture.

A higher house density makes it easier for mosquitoes to transmit DHF between more people in the house. This 
can help explain why this study in Kupang City found that DHF incidence was related more to house density than to house size. That is, the higher the density of the house, the higher the risk of dengue incidence. However, low density houses can also have a high risk of dengue transmission. This is because even if the house density is low, if the mobility of people at home is also low based on more routine activities without moving from the same position, the possibility of mosquito bites will be higher than for those who are more active in the house. Previous studies have also shown that the frequency of mosquitoes biting inside a house is influenced by the activity of people inside the house (OR 3.3). People who are less active have a 3.3 times higher risk of being bitten by mosquitoes than those who are active. ${ }^{14}$ And, the higher the risk of mosquito bites, the higher the risk of dengue infection.

This study in Kupang City also found a relationship between home lighting and dengue incidence. This is the same as the study in Surabaya and Depok, which also found a relationship between lighting and DHF incidence. ${ }^{15,16}$ However, it is not like the study in Banyumas that did not find a relationship between dark rooms and DHF incidence. ${ }^{17}$ The relationship between lighting and the incidence of dengue can be explained by mosquitoes' preference for darkness both inside and outdoors. Mosquitoes need places that are not directly exposed to sunlight to lay their eggs or to rest during their gonotropic cycles. This means that dark places will have a high density of Aedes mosquitoes, such as in bedrooms, toilets, bathrooms, kitchens, under furniture, or behind hanging objects such as clothes and curtains. ${ }^{18}$ There was a relationship between lighting and the existence of Aedes larvae in water container, with the incidence of DHF and that is also related to man hour density (MHD). ${ }^{19}$

This study found that house temperature had no significant relationship with DHF incidence in Kupang City. This finding differs from a previous study in Aceh that found a significant relationship between house temperature and dengue incidence. ${ }^{14}$ The temperature of houses in Kupang City is not related to DHF incidence because in this study, the house temperature between DHF and non-DHF patient groups did not show a difference. However, in general, the temperature in the city of Kupang allows optimal development of the virus in mosquitoes' bodies. This is according to the theory that the extrinsic incubation period of Dengue virus in mosquito bodies can last seven days at $32^{\circ}-35^{\circ} \mathrm{C}$ and 12 days at $30^{\circ} \mathrm{C}$.

Tolerance of temperature by each mosquito is different depending on the species and geographical location of the mosquito; the tolerance level for those that live in polar regions differs from that of mosquitoes that live in the tropics. Temperature affects egg development and blood sucking activity. The role of home temperature is very important in every stage of mosquito development and every stage of development requires different temperatures. For example, egg hatching requires a temperature of $\geq 13^{\circ} \mathrm{C}$; egg laying requires a temperature of $>$ $22^{\circ} \mathrm{C}$; the emergence from the pupae requires temperatures $>18^{\circ} \mathrm{C}$; and mosquito growth stops at temperatures $<10^{\circ} \mathrm{C}$ or $>40^{\circ} \mathrm{C}$, with the optimum temperature of mosquito development at $25^{\circ}-27^{\circ} \mathrm{C} .{ }^{20}$ The room temperature depends on the temperature outside the house. During the rainy season, the temperature is relatively low and the humidity is high, and during the dry season, the air temperature is relatively high with low humidity. ${ }^{21}$

The rate of egg development and hatching into larvae are also influenced by water temperature. ${ }^{22}$ The role of the temperatures described thus far is very important in each development stage of eggs, larvae, and pupae. This has been proven in a Banjarbaru study that found a relationship between water temperature and the presence of larvae in water container. ${ }^{23}$ This is different from a Makassar study that did not find any correlation between water temperature and the presence of larvae in water container. ${ }^{24}$

The use of water in the city of Kupang still did not meet minimum requirements and was therefore statistically associated with DHF incidence. For urban areas or big cities, water use should be 200-400 liters/day/person, but in Kupang City is just 48.632 liters per person/day, which is lower than the minimum requirement. Water is a basic necessity for life; people need water daily for drinking, bathing, washing, and so on. A small water supply requires people to save on water use. The community also has to save water for daily needs in numerous containers that are not cleaned as often as they should be because of the limited water supply. In turn, this condition invites mosquitoes to lay eggs and breed in these containers. Many of these containers are found to have larvae, increasing mosquito density and therefore increasing the risk of DHF transmission.

Provision of water is less likely to have an impact on the presence of water borne disease. DHF is not included in water borne disease, but DHF incidence is also related to the water supply because mosquitoes lay eggs and the development of praimago stadium takes place in water. The lack of water supply in Kupang City causes the community to try to save water, which in turns means that the water container is rarely cleaned and water is stored in various water containers. Water in containers is often stored for a long time without washing the water containers regularly at least once a week, so they are a potential place for Aedes mosquitoes to breed.

This study showed that non-permanent homes have a 9.24 times higher risk of dengue fever occurrence than permanent homes. This is because houses that are not 
permanent are usually made of wood or a mixture of wood and cement, and they usually have less ventilation and lighting. As a result, rooms inside the house will be more dark and the density of mosquitoes will higher. In turn, this causes the possibility of a higher risk of dengue transmission in non-permanent homes. This finding is different from a previous study which found that house wall conditions are not related to DHF incidence. ${ }^{25}$

This study showed that unqualified ventilation that is less than $10 \%$ of floor size will increase the risk of getting DHF by 7.184 compared to qualified ventilation. If ventilation is not qualified, rooms remain dark and moist instead of allowing air and light to exit, and mosquitoes enjoy these conditions, so mosquitoe density will be higher. The extent of ventilation is related to DHF incidence, and this finding is in accordance with a study in Surabaya that found a relationship between ventilation and DHF incidence. ${ }^{15}$

The rainy season usually causes houses to be darker and more, and mosquitoes favor these conditions, so dark and humid places will tend to have a higher density of mosquitoes than bright places with fresher air. Many homes with plenty of ventilation were found to be keeping it closed, so they are not fulfilling their role in allowing air and light to circulate, causing rooms to remain dark and moist. This study found a higher risk of dengue incidence in areas of lower ventilation, meaning that the more open the ventilation, the lower the risk of dengue incidence.

Without air, there is no life. The role of ventilation is to allow air to circulate through the house, so air circulation depends on the presence of ventilation. Ventilation also affects humidity and room temperature by being a place of light entry. ${ }^{21}$ In addition, the ventilation areas and conditions affect DHF incidence, so there is a need to increase the amount or extent of ventilation and keep the ventilation always open so that air and light can enter the home, preventing room humidity, cooler air temperatures, and fresher air. These conditions contribute to a decrease in mosquito density because mosquitoes uncategorically dislike them.

Larvae density is also high in the city of Kupang, and this aligns with a previous study in Kupang City which found that only $95.7 \%$ of people are taking preventive actions against DHF by washing and drying containers; only $90.6 \%$ by closing water containers, and only $54.7 \%$ by burying and recycling used materials. ${ }^{26}$ It is necessary to eliminate larvae by draining, cleaning, and brushing water containers at least once a week without throwing away the clean water.

Types of clean water facilities in this study included mostly dug wells and water piping, but these did not affect DHF incidence. A previous study found that clean water facility type is related to larval density. It has also been reported that the type of water facility is related to the presence of larvae, with the risk of non piping 13.78 times that of what is found for larvae compared to piping type. ${ }^{27}$ A previous study found that water piping facilities are at low risk for larvae because the water piping flows more routinely. In Kupang City, water often flows only once or twice a week, so it does not meet the people's need for water. In response, many people use boreholes both privately owned or buy from tank cars that operate every day with price more expensive than water piping.

Most clean water facilities in Kupang City are not self owned, which means they have a 2.196 times higher risk of contracting DHF compared to those who own clean water facilities. As many as $70.3 \%$ of DHF sufferers do not own their own clean water facilities, so they must get their clean water for daily needs from a neighbor, a public place, or even from a tank car. If sourced from a tank car, it costs IDR 75,000 to IDR 90,000 per tank (5000 liters). The lack of clean water supply has caused people in Kota Kupang to try to save on water use. Not only do they often they have to buy water from tankers, but they must also prepare large or medium-sized shelters as storage areas for water or small reservoirs in large quantities.

Understanding the difficulty of accessing clean water and the large expense to get clean water sheds light on why a community might seldom drain their clean water supply over the long term and is more likely to keep the water stores full for as long as possible, increasing the likelihood of breeding mosquitoes and increasing the risk of dengue. This condition will get worse because many communities in Kupang City do not understand that breeding sites for Aedes sp as vectors of DHF not only include bathtubs, but also water container lids (90.6\%) and pouring temefos in water containers $(88.9 \%) .{ }^{26} \mathrm{In}$ this case, both the government and the community are responsible for preventive action. The government must increase public access to clean water, such as by increasing piped water discharge, increasing the frequency of water flowing into people's houses, and maintaining health promotions about the importance of always cleaning water containers so they do not become a mosquito breeding place.

\section{Conclusion}

The risk factors for DHF not only include climate conditions such as rainfall, humidity, and temperature, but also house conditions as found in this study. This study found a significant relationship between DHF incidence and house conditions; specifically house lighting ( $\mathrm{p}$-value $=0.038)$, water usage ( $\mathrm{p}$-value $=0.004)$, wall construction $(p$-value $=0.000)$, ventilation size $(p$-value $=0.000)$, and ownership of clean water facilities ( $p$-value $=0.046$ ). 


\section{Recommendation}

Communities are advised to ventilate houses by at least $10 \%$ of the house size and to keep the ventilation continually open for air exchange and to allow sunlight into the house. The government must increase the quality and quantity of the clean water supply for the community and promote cleaning water reservoirs routinely by brushing containers at least once a week.

\section{References}

1. Ali KM, Asha AV, Aneesh EM. Bioecology and vectorial capacity of aedes mosquitoes (Diptera: Culicidae) in Irinjalakuda Municipality, Kerala, India in relation to disease transmission. International Journal of Current Research and Academic Review. 2014; 2(4): 43-9.

2. Halstead SB. Dengue virus - mosquito interactions. Annual Reviews Entomology. 2008; 53(15): 1-15.19.

3. World Health Organization. Dengue guidelines for diagnosis, treatment, prevention and control: new edition. World Health Organization. 2009. Available from: http://www.who.int/iris/handle/10665/44188

4. Stanaway JD, Shepard DS, Undurraga EA, Halasa YA, Coffeng LE, Brady OJ, et al. The global burden of dengue: an analysis from the global burden of disease study 2013. Lancet Infectious Disease. 2016; 16(6): 712-23.

5. Umoh A, Akpan A, Jacob B. Rainfall and relative humidity occurrence patterns in Uyo Metropolis, Akwa Ibom State, South-South Nigeria. IOSR Journal of Engineering. 2013; 3(8): 27-31.

6. Nazneen S. Molecular typing of dengue virus isolated from field caught mosquito specimens by reverse transcriptase polymerase chain reaction (RT-PCR) molecular typing of dengue virus isolated from field caught mosquito specimens by reverse transcriptase polymerase c. Bangladesh: University of Dhaka; 2014.

7. Morin CW, Comrie AC, Ernst K. Climate and Dengue Transmission: Evidence and Implications. Environmental Health Perspectives [Internet]. 2013;121(11-12):1264-72. Available from: http://ehp.niehs.nih.gov/1306556/

8. Badan Meteorologi Klimatologi, dan Geofisika. Buletin pemantauan ketahanan pangan Indonesia (fokus utama: cuaca ekstrim). November 2016; 4. https://documents.wfp.org/stellent/groups/public/documents/ena/wfp289822.pdf

9. Health Office Kupang City. Recapitulation of surveillance data from Kupang City. Kupang; 2015.

10. Gordon JE. The epidemiology of accident. American Journal of Public Health Research. 1949; 39: 504-15.

11. Achmadi UF. Manajemen penyakit berbasis wilayah. Kesmas: National Public Health Journal. 2009; 3(4): 147-53.

12. Djati AP, Widiastuti D. Several environmental factors related with endemicity status of dengue haemorrhagic fever. Health Science Indonesia. 2012; 3(1): 27-30.

13. Medical Research Institute and Dengue Coordination Unit. Practical manual and gudelines for dengue vector surveillance. Sri Lanka: Medical
Research Institute and Dengue Coordination Unit; 2011.

14. Sofia, Suhartono, Wahyuningsih NE. Hubungan kondisi lingkungan rumah dan perilaku keluarga dengan kejadian demam berdarah dengue di Kabupaten Aceh Besar. Jurnal Kesehatan Lingkungan Indonesia. 2014; 13(1): 30-7.

15. Steven. The role factors of demography characteristic, nutrition state, environtment, knowledge, attitude, and community practices toward dengue haemoragic fever incidences at Rangkah Health Centre Territory, Surabaya City. Jurnal Widya Medika. 2014; 2(1).

16. Wahyono TYM, Haryanto B, Mulyono S, Adiwibowo A. Faktor-faktor yang berhubungan dengan kejadian demam berdarah dan upaya penanggulangannya di Kecamatan Cimanggis, Depok, Jawa Barat. Buletin Jendela Epidemiologi. Agustus 2010; 2: 31-43.

17. Kanigia TE, Cahyono T, Gunawan AT. Faktor-faktor yang berisiko dengan kejadian demam berdarah dengue di Kecamatan Purwokerto Timur Kabupaten Banyumas Tahun 2016. Keslingmas. 2016; 35(Des): 278396.

18. World Health Organization-South East Asia Regional Office. Comprehensive guidelines for prevention and control of dengue and dengue haemorrhagic fever. World Health Organization Regional Publication South East Asia Regional Office. India; 2011: 159-68.

19. Wanti, Yudhastuti R, Yotopranoto S, Notobroto HB, Subekti S, Umniati SR. Container positivity and larva distribution based on the container characteristic. International Journal of Public Health Science (IJPHS) [Internet]. 2017; 6(3): 237-42. Available from: http://www.iaesjournal.com/online/index.php/IJPHS/article/view/163 36

20. Hopp MJ, Foley JA. Global-Scale Relationships Between Climate and the Dengue Fever Vector, Aedes aegypti . Climatic Change . 2001; 48: 441-63.

21. Moerdjoko. Kaitan sistem ventilasi bangunan dengan keadaan mikroorganisme udara. Dimensi Teknik Arsitektur. 2004; 32(1): 89-93.

22. Embong NB. Pengaruh suhu terhadap angka penetasan telur. E-Jurnal Medika. 2016; 5(12): 1-8.

23. Ridha MR, Rahayu N, Rosvita NA, Setyaningtyas DE. The relation of environmental condition and container to the existence of the Aedes aegypti larvae in dengue haemorrhagic fever endemic areas in Banjarbaru. Jurnal Buski. 2013; 4(3): 133-7.

24. Sallata MHE. Relation of physical and chemical environmental characteristics with existence of Aedes aegypti larvae in DHF endemic areas in the City of Makassar. Makassar: Universitas Hasanuddin; 2014.

25. Sulistyorini E. Faktor penentu keberadaan larva Aedes spp pada daerah endemis demam berdarah dengue tertinggi dan terendah di Kota Bogor. Bogor: Institut Pertanian Bogor; 2016.

26. Wanti W, Sila O, Irfan I, Sinaga E. Transovarial transmission and dengue virus serotypes in aedes aegypti in Kupang. Kemas: Jurnal Kesehatan Masyarakat. 2016; 12(1): 131-8.

27. Riandi MU, Hadi UK, Soviana S. Karakteristik habitat dan keberadaan larva aedes spp pada wilayah kasus demam berdarah dengue tertinggi dan terendah di Kota Tasikmalaya. Aspirator. 2017; 9(1): 43- 50. 